\title{
An investigation on factors influencing electronic banking adoption in private banks versus public banks
}

\author{
Ali Alikhani ${ }^{a^{*}}$ and Malihe Hosseinzadeh Davarzani ${ }^{\mathbf{b}}$
}

${ }^{a}$ Assist. Prof. \& Faculty Member, Department of management, School of Management and Human Sciences, Tehran North Branch, Islamic Azad University (IAU), Tehran, Iran

${ }^{b}$ M.Sc. Student, Department of management, School of Management and Human Sciences, Tehran north branch, Islamic Azad University (IAU), Iran

\section{H R O N I C L E}

Article history:

Received Feb 28, 2013

Received in revised format

19 September 2013

Accepted 23 October 2013

Available online

December 12013

\section{Keywords:}

Technology Acceptance Model

Electronic banking

Computer self-efficacy

Ease of use

\section{A B S T R A C T}

The movement of industrial societies towards implementation of information technology has begun and it has gained moment since early $90^{\text {th }}$ and presently the speed of this movement is well obvious in less developed countries, including Iran. Internet Banking is one of the most tangible trends in today's electronic commerce. It has direct relationship with the perception of the service qualities not only because of unique absorption of the internet, but also because of ecommerce, acceptance of internet services of banks by clients and the tendency for using such services. This paper investigates different factors influencing on acceptance of electronic banking in private banks versus public banks in a case study of two Iranian banks namely; Eqtesade Novin and Sepah using Technology Acceptance Model (TAM). Correlation test reveals that there was a positive and significant relationship between clients of private and public bank on five factors associated with TAM. In addition, structural equation method was used for investigation of relationships in offered model. In conclusion, all primary and secondary hypotheses for clients of private and public bank were confirmed.

\section{Introduction}

During the past few years, there have been tremendous efforts on online banking but there are several challenges to encourage all people to do their daily banking activities through internet. Aladwani (2001) reported the results of a quantitative investigation of the perceptions of banks' executive and information technology (IT) managers and potential customers on drivers, development challenges, and expectations of online banking. Bradley and Stewart (2002) performed an empirical investigation on drivers and inhibitors of Internet banking. Byers and Lederer (2001) explained the impact of electronic distribution technologies such as PC banking on the choice of a bank's distribution strategy. They presented a competitive framework of distribution strategy choice, including heterogeneous

* Corresponding author. Tel: +98-912-2995919

E-mail addresses: aalikhani52@yahoo.com (A. Alikhani)

C) 2013 Growing Science Ltd. All rights reserved.

doi: $10.5267 / \mathrm{j} . \mathrm{ms} 1.2013 .12 .001$ 
consumers and banks, which allowed a rich variety of customer preference and technology cost parameters. The analysis suggested that changing consumer behavior and attitudes, instead of banks' cost structure with new technologies could substantially influence on the bank's distribution strategy choice.

Liao and Cheung (2002) performed an empirical investigation on internet-based e-banking and consumer attitudes. The survey was established in Singapore, because its geography and welldeveloped infrastructure implied similar and small physical- and tele-communication expenses, thereby highlighting the changes between traditional and Internet-based retail banking upon the latter's introduction. They reported that expectations of accuracy, security, network speed, userfriendliness, user involvement and convenience were the most essential quality attributes underlying perceived usefulness. They also reported that willingness to apply depended substantially on the first five factors, allowing the interdependencies or marginal rates of substitution between them to be estimated.

Corrocher (2006) examined the determinants of adoption of Internet banking among Italian retail banks. More specifically, the study concentrated at investigating the nature of Internet banking in association with traditional banking activity. He analyzed the role of firm-specific and marketspecific characteristics in influencing the decision to provide financial services via the Internet. The empirical analysis stated that the adoption of Internet banking depends entirely on the characteristics of traditional banking activities, specifically in terms of existing networks of distribution as well as customers. First, banks with high branching intensity adopted more slowly than banks with a few branches in place. Second, adoption was negatively influenced by the existence of a large customer base. Singh and Malhotra (2004) helped fill significant gaps in knowledge about the Internet banking landscape in India.

\section{The proposed method}

This paper investigates different factors influencing on acceptance of electronic banking in private banks versus public banks in a case study of two Iranian banks namely; Eqtesade Novin and Sepah using Technology Acceptance Model (TAM) (Davis et al., 1989; Burton-Jones \& Hubona, 2006; McKechnie et al., 2006). The proposed study chooses a sample of 300 (217 male and 83 female) and 121 (120 male and 92 female) people from regular customers of Sepah and Eqtesade Novin. Fig. 1 demonstrates the summary of their personal characteristics of the participants.

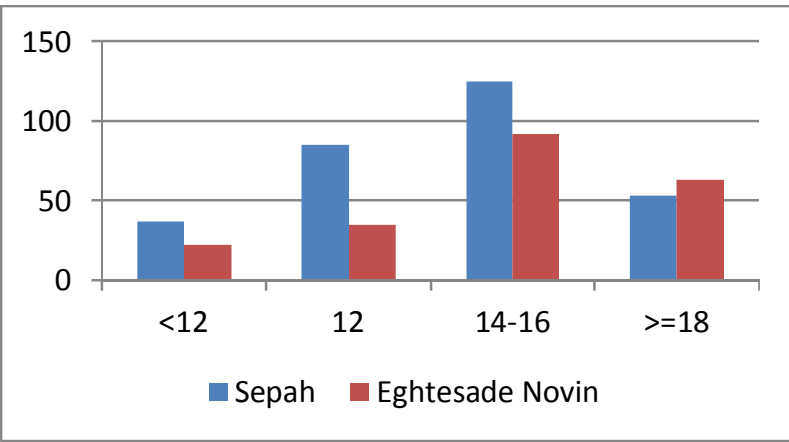

Years of education

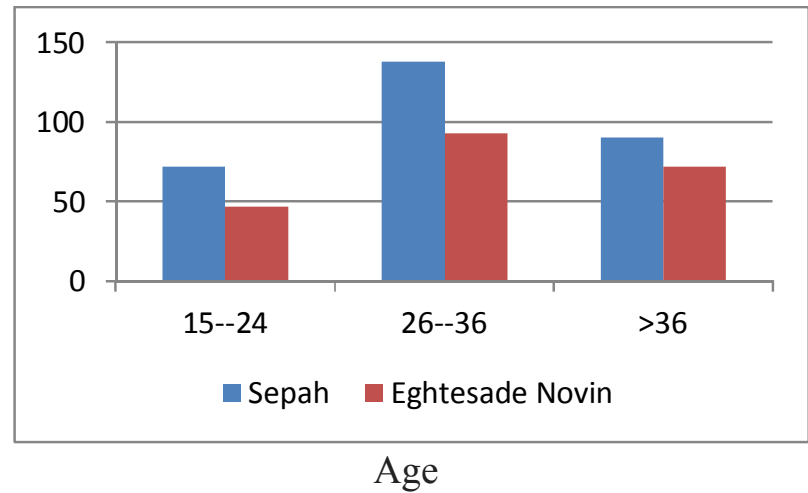

Age

Fig. 1. Personal characteristics of the participants

As we can observe from the results of Fig. 1, most participants had university background and they are middle aged people. There is one main hypothesis associated with the proposed study of this paper as follows,

Main hypothesis: Important factors influencing electronic banking are meaningful in both private and public Iranian banks. 
There are five sub-hypotheses associated with the proposed study of this paper as follows,

1. Self-efficiency computer influences positively on electronic banking.

2. The benefits of electronic banking influence positively on electronic banking.

3. Perceived ease of use electronic banking influences electronic banking.

4. Perceived usefulness of electronic banking influences electronic banking.

5. Having good attitude towards learning electronic banking influences electronic banking.

The proposed study uses designs a questionnaire in Likert scale and uses different statistical observation to examine various hypotheses of the survey.

\section{The results}

In this section, we present details of our findings on testing various hypotheses of the survey. Table 1 shows mean and standard deviation associated with each factor of the proposed model.

Table 1

The summary of some basic statistics associated with different components of TAM

\begin{tabular}{ccccc}
\hline & \multicolumn{2}{c}{ Eghtesad novin } & \multicolumn{2}{c}{ Sepah } \\
\hline & Mean & Standard dev. & Mean & Standard dev. \\
\hline Perceived usefulness & 4.11 & 0.85 & 3.45 & 0.88 \\
Self-efficiency computer & 4.12 & 0.94 & 2.73 & 0.91 \\
Perceived usefulness & 4.18 & 0.89 & 3.26 & 0.79 \\
Perceived ease of use & 4.22 & 0.73 & 3.67 & 0.86 \\
Attitude & 4.35 & 0.77 & 2.81 & 0.79 \\
ATM & 4.23 & 0.84 & 3.11 & 0.91 \\
\hline
\end{tabular}

As we can observe from the results of Table 1, all components maintain high numbers, which are well above the minimum acceptable limits for two private and public banks. Table 2 demonstrates the summary of our results.

Table 2

The summary of statistical observations on testing various hypotheses

\begin{tabular}{|c|c|c|c|c|c|c|c|c|c|}
\hline \multirow{3}{*}{$\begin{array}{r}\text { variable } \\
\text { Latent }\end{array}$} & \multirow{3}{*}{ Manifest } & \multicolumn{4}{|c|}{ Eghtesad novin } & \multicolumn{4}{|c|}{ Sepah } \\
\hline & & \multicolumn{2}{|c|}{ LAMBDA } & \multirow{2}{*}{$\mathrm{t}$} & \multirow{2}{*}{$\begin{array}{c}\text { Cronbach's } \\
\text { alpha }\end{array}$} & \multicolumn{2}{|c|}{ LAMBDA } & \multirow{2}{*}{$\mathrm{t}$} & \multirow{2}{*}{$\begin{array}{l}\text { Cronbach's } \\
\text { alpha }\end{array}$} \\
\hline & & Standardized & estimate & & & Standardized & estimate & & \\
\hline \multirow{4}{*}{ Acc } & Accl 1 & 0.77 & 0.81 & 16.23 & \multirow{4}{*}{0.75} & 0.78 & 0.81 & 16.74 & \multirow{4}{*}{0.79} \\
\hline & Acc2 & 0.76 & 0.80 & 16.09 & & 0.78 & 0.82 & 16.81 & \\
\hline & Acc 3 & 0.79 & 0.83 & 16.75 & & 0.79 & 0.82 & 16.97 & \\
\hline & Acc 4 & 0.78 & 0.82 & 16.51 & & 0.78 & 0.81 & 16.75 & \\
\hline \multirow{4}{*}{ Att } & Att1 & 0.79 & 0.82 & 16.16 & \multirow{4}{*}{0.77} & 0.83 & 0.87 & 17.99 & \multirow{4}{*}{0.75} \\
\hline & Att2 & 0.79 & 0.83 & 16.21 & & 0.75 & 0.78 & 15.62 & \\
\hline & Att3 & 0.79 & 0.83 & 16.21 & & 0.75 & 0.79 & 15.72 & \\
\hline & Att4 & 0.79 & 0.83 & 16.22 & & 0.83 & 0.87 & 17.98 & \\
\hline \multirow{4}{*}{ Seff } & Seff1 & 0.79 & 0.82 & 16.18 & \multirow{4}{*}{0.79} & 0.79 & 0.83 & 16.78 & \multirow{4}{*}{0.72} \\
\hline & Seff 2 & 0.79 & 0.82 & 16.21 & & 0.81 & 0.85 & 17.32 & \\
\hline & Seff3 & 0.79 & 0.83 & 16.21 & & 0.80 & 0.84 & 16.93 & \\
\hline & Seff4 & 0.79 & 0.82 & 16.20 & & 0.74 & 0.78 & 15.46 & \\
\hline \multirow{3}{*}{ Ben } & Ben1 & 0.81 & 0.85 & 16.61 & \multirow{3}{*}{0.74} & 0.80 & 0.84 & 16.94 & \multirow{3}{*}{0.75} \\
\hline & Ben2 & 0.81 & 0.85 & 16.54 & & 0.79 & 0.83 & 16.80 & \\
\hline & Ben3 & 0.80 & 0.84 & 16.31 & & 0.81 & 0.85 & 17.14 & \\
\hline \multirow{5}{*}{ Peou } & Peoul & 0.78 & 0.82 & 15.94 & \multirow{5}{*}{0.76} & 0.79 & 0.83 & 16.85 & \multirow{5}{*}{0.77} \\
\hline & Peou2 & 0.79 & 0.83 & 16.26 & & 0.79 & 0.83 & 16.76 & \\
\hline & Peou3 & 0.77 & 0.81 & 15.71 & & 0.75 & 0.79 & 15.66 & \\
\hline & Peou4 & 0.80 & 0.84 & 16.44 & & 0.79 & 0.83 & 16.67 & \\
\hline & Peou5 & 0.80 & 0.84 & 16.61 & & 0.84 & 0.88 & 18.10 & \\
\hline \multirow{4}{*}{$\mathrm{Pu}$} & Pul & 0.82 & 0.86 & 16.77 & \multirow{4}{*}{0.81} & 0.78 & 0.81 & 16.50 & \multirow{4}{*}{0.75} \\
\hline & $\mathrm{Pu} 2$ & 0.80 & 0.84 & 16.39 & & 0.77 & 0.81 & 16.32 & \\
\hline & Pu3 & 0.80 & 0.84 & 17.28 & & 0.80 & 0.83 & 17.03 & \\
\hline & $\mathrm{Pu} 4$ & 0.82 & 0.86 & 17.78 & & 0.82 & 0.86 & 17.72 & \\
\hline
\end{tabular}

Acc=Accepting electronic banking, Att=attitude, Seff=self-efficiency computer, Ben=benefit, Peou=perceived ease of use, Pu=perceived usefulness 
According to the results of Table 2, Cronbach alphas are well above the minimum acceptable limits. In addition, t-student values are also statistically significant. Next, we present details of the implementation of structural equation modeling (Fornell \& Larcker, 1981a, 1981b; Bagozzi, 1981; Bollen, 1998). All implementations have been applied using LISREL software package (Jöreskog \& Sörbom, 1989; Fornell \& Bookstein, 1982; Anderson \& Gerbing, 1988; Bagozzi \& Yi, 1988; Byrne, 1989). Fig. 2 demonstrates the results of our survey.

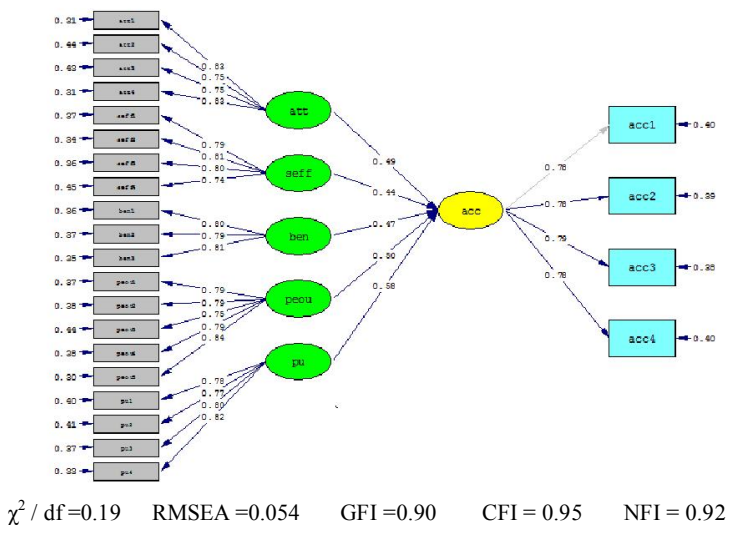

Standard coefficients for Bank Sepah

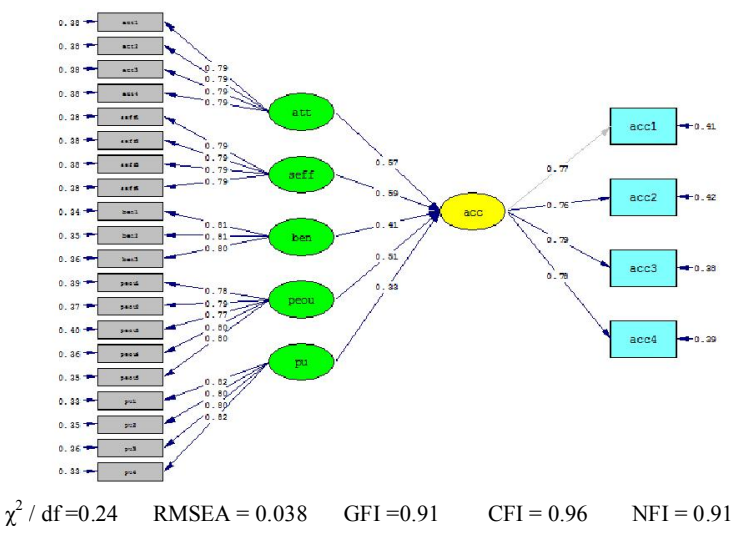

Standard coefficients for Bank Eghtesad novin

Fig. 2. The results of the implementation of structural equation modeling

According to the results of Fig. 1, all statistics are within acceptable limits, which validates the implementation of structural equation modeling. Table 3 shows details of t-student values on testing various components of the survey.

Table 3

The summary of t-student values for the implementation of structural equation modeling

\begin{tabular}{ccccccc}
\hline & \multicolumn{3}{c}{ Eghtesad novin } & \multicolumn{4}{c}{ Sepah } \\
\hline & $\beta$ & t-value & Result & $\beta$ & t-value & Results \\
\hline Perceived usefulness & 0.47 & 3.57 & $\sqrt{ }$ & 0.41 & 3.11 & $\sqrt{ }$ \\
Self-efficiency computer & 0.44 & 3.17 & $\sqrt{ }$ & 0.59 & 4.73 & $\sqrt{ }$ \\
Perceived usefulness & 0.57 & 4.45 & $\sqrt{ }$ & 0.51 & 4.46 & $\sqrt{ }$ \\
Perceived ease of use & 0.50 & 4.48 & $\sqrt{ }$ & 0.33 & 2.47 & $\sqrt{ }$ \\
Attitude & 0.49 & 4.45 & $\sqrt{ }$ & 0.57 & 4.64 & $\sqrt{ }$ \\
\hline
\end{tabular}

The results of Table 3 indicate that all coefficients are statistically significance $(\alpha=5 \%)$. In other words, five components including perceived usefulness, self-efficiency computer, perceived usefulness, perceived ease of use and attitude influence positively on adoption of electronic banking.

\section{Conclusion}

In this paper, we have presented an empirical investigation to study the effects of five technology acceptance method (TAM) components including perceived usefulness, self-efficiency computer, perceived usefulness, perceived ease of use and attitude influence positively on adoption of electronic banking. The proposed model designed a questionnaire and distributed it among some regular customers of one private and one governmental bank in city of Tehran, Iran. The results have indicated that all five components positively influence on adoption of electronic banking. In addition, the results of this survey are consistent with Berger (2009), Venkatesh et al. (2003), Wan et al. (2005), Yi and Hwang (2003) and Yousafzai et al. (2003). 


\section{Acknowledgement}

The authors would like to thank the anonymous referees for constructive comments on earlier version of this work.

\section{References}

Aladwani, A. M. (2001). Online banking: a field study of drivers, development challenges, and expectations. International Journal of Information Management,21(3), 213-225.

Anderson, J. C., \& Gerbing, D. W. (1988). Structural equation modeling in practice: A review and recommended two-step approach. Psychological bulletin, 103(3), 411.

Bagozzi, R. P. (1981). Evaluating structural equation models with unobservable variables and measurement error: a comment. Journal of Marketing Research, 375-381.

Bagozzi, R. P., \& Yi, Y. (1988). On the evaluation of structural equation models. Journal of the academy of marketing science, 16(1), 74-94.

Berger, S. C. (2009). Self-service technology for sales purposes in branch banking: The impact of personality and relationship on customer adoption. International Journal of Bank Marketing, 27(7), 488-505.

Bollen, K. A. (1998). Structural equation models. John Wiley \& Sons, Ltd.

Bradley, L., \& Stewart, K. (2002). A Delphi study of the drivers and inhibitors of Internet banking. International Journal of Bank Marketing, 20(6), 250-260.

Burton-Jones, A., \& Hubona, G. S. (2006). The mediation of external variables in the technology acceptance model. Information \& Management, 43(6), 706-717.

Byrne, B. M. (1989). A primer of LISREL: Basic applications and programming for confirmatory factor analytic models. Springer-Verlag Publishing.

Byers, R. E., \& Lederer, P. J. (2001). Retail bank services strategy: a model of traditional, electronic, and mixed distribution choices. Journal of Management Information Systems, 18(2), 133-156.

Corrocher, N. (2006). Internet adoption in Italian banks: An empirical investigation. Research Policy, 35(4), 533-544.

Davis, F. D., Bagozzi, R. P., \& Warshaw, P. R. (1989). User acceptance of computer technology: a comparison of two theoretical models. Management science, 35(8), 982-1003.

Fornell, C., \& Larcker, D. F. (1981a). Evaluating structural equation models with unobservable variables and measurement error. Journal of marketing research, 39-50.

Fornell, C., \& Larcker, D. F. (1981b). Structural equation models with unobservable variables and measurement error: Algebra and statistics. Journal of marketing research, 382-388.

Fornell, C., \& Bookstein, F. L. (1982). Two structural equation models: LISREL and PLS applied to consumer exit-voice theory. Journal of Marketing research, 440-452.

Jöreskog, K. G., \& Sörbom, D. (1989). LISREL 7: A guide to the program and applications (Vol. 2). Chicago: Spss.

Liao, Z., \& Cheung, M. T. (2002). Internet-based e-banking and consumer attitudes: an empirical study. Information \& Management, 39(4), 283-295.

McKechnie, S., Winklhofer, H., \& Ennew, C. (2006). Applying the technology acceptance model to the online retailing of financial services. International Journal of Retail \& Distribution Management, 34(4/5), 388-410.

Singh, B., \& Malhotra, P. (2004). Adoption of Internet banking: An empirical investigation of Indian banking Sector. Journal of Internet Banking and Commerce, 9(2), 9909-05.

Venkatesh, V., Morris, M. G., Davis, G. B., \& Davis, F. D. (2003). User acceptance of information technology: Toward a unified view. MIS quarterly, 425-478.

Wan, W. W., Luk, C. L., \& Chow, C. W. (2005). Customers' adoption of banking channels in Hong Kong. International Journal of Bank Marketing, 23(3), 255-272. 
Yi, M. Y., \& Hwang, Y. (2003). Predicting the use of web-based information systems: self-efficacy, enjoyment, learning goal orientation, and the technology acceptance model. International journal of human-computer studies, 59(4), 431-449.

Yousafzai, S. Y., Pallister, J. G., \& Foxall, G. R. (2003). A proposed model of e-trust for electronic banking. Technovation, 23(11), 847-860. 